\title{
Motivasi Belajar Siswa Sekolah Dasar Di Kota Magelang
}

Martia Yosi Nurfa Indah(1)

Universitas Muhammadiyah Magelang

yofandamrt09@gmail.com

\section{Maya Mardi Yanti(2)}

Universitas Muhammadiyah Magelang

mayamardiyanti6@mail.com

\section{Yollawati Arifi(3)}

Universitas Muhammadiyah Magelang yollaarifi1@gmail.com

\author{
Ade Ayu Mutiara Pawestri(4) \\ Universitas Muhammadiyah Magelang \\ aayu8429@gmail.com
}

\section{Hermahayu(5)}

Universitas Muhammadiyah Magelang

hermahayu@ummgl.ac.id

DOI: 10.23917/varidika.v32i1.11141

\begin{tabular}{|c|c|}
\hline Submission & ABSTRACT \\
\hline Track: & \\
\hline Received: & $\begin{array}{l}\text { Student learning motivation refers to how students get the urge to } \\
\text { learn. Learning motivation can be obtained from three aspects, }\end{array}$ \\
\hline 27 Febuary 2020 & namely extrinsic, intrinsic, and combination motivation. This \\
\hline Final Revision: & $\begin{array}{l}\text { study aims to determine the analysis related to how the level of } \\
\text { motivation for elementary school student learning is influenced }\end{array}$ \\
\hline 27 March 2020 & $\begin{array}{l}\text { by intrinsic factors, extrinsic factors, as well as a combination of } \\
\text { both factors. The method used in this research is descriptive }\end{array}$ \\
\hline Available online: & $\begin{array}{l}\text { quantitative, with data collection methods that refer to the Scale } \\
\text { of Intrinsic versus Extrinsic Orientation in The Classroom (Susan }\end{array}$ \\
\hline 31 June 2020 & $\begin{array}{l}\text { Harter's Intrinsic Orientation Scale in Classes) owned by Susan } \\
\text { Harter in 1981. Based on the analysis using the SPSS program, }\end{array}$ \\
\hline Corresponding & as many as $50,4 \%$ (57 students) of 113 elementary school \\
\hline Author: & $\begin{array}{l}\text { students in Magelang City had a high level of motivation to learn } \\
\text { combination. While the remaining } 49.6 \%(35 \text { students }) \text { are }\end{array}$ \\
\hline Martia Yosi Nurfa Indah & $\begin{array}{l}\text { divided into categories of extrinsic learning motivation } \\
\text { categories, namely } 31 \% \text { of } 113 \text { students, and } 18.6 \% \text { (21 students) }\end{array}$ \\
\hline hermahayu@ummgl.ac & $\begin{array}{l}\text { of } 113 \text { students have a tendency for intrinsic learning motivation. } \\
\text { Kata kunci: motivasi belajar, motivasi ekstinsik, motivasi } \\
\text { kombinasi }\end{array}$ \\
\hline
\end{tabular}

Submission

Track

27 Febuary 2020

Final Revision:

27 March 2020

Author:

Martia Yosi Nurfa Indah

hermahayu@ummgl.ac.id
Student learning motivation refers to how students get the urge to learn. Learning motivation can be obtained from three aspects, namely extrinsic, intrinsic, and combination motivation. This study aims to determine the analysis related to how the level of motivation for elementary school student learning is influenced by intrinsic factors, extrinsic factors, as well as a combination of both factors. The method used in this research is descriptive quantitative, with data collection methods that refer to the Scale of Intrinsic versus Extrinsic Orientation in The Classroom (Susan Harter in 1981. Based on the analysis using the SPSS program, as many as 50 , 4\% (57 students) of 113 elementary school students in Magelang City had a high level of motivation to learn combination. While the remaining 49.6\% (35 students) are divided into categories of extrinsic learning motivation categories, namely $31 \%$ of 113 students, and $18.6 \%$ (21 students) Kata kunci: motivasi belajar, motivasi ekstinsik, motivasi kombinasi 


\section{PENDAHULUAN}

Beberapa waktu lalu, tepatnya tahun 2018 menurut data yang diperoleh dari PISA (Programme for International Student Assesment) kualitas pendidikan di Indonesia mengalami penurunan sejak dari tahun 2015. Hal tersebut dibuktikan karena adanya studi yang mengkaji sebanyak 600.000 anak berusia 15 tahun dari 79 negara di dunia yang dilaksanakan tiap 3 tahun sekali. Hasilnya menunjukkan bahwa kemampuan membaca pelajar Indonesia memperoleh skor 371, kemampuan matematika 379, dan kemampuan kinerja sains 396. Apabila dibandingkan dengan tahun 2015, performa Indonesia terlihat menurun (Permana, 2019).

Fenomena kasus yang terjadi di masyarakat yang menunjukkan adanya keterkaitan kasus terhadap motivasi belajar, yaitu tentang kualitas pendidikan di Indonesia yang masih rendah (Fauzie, 2018). Hal tersebut tentunya berkaitan dengan motivasi belajar karena apabila secara teknis pelaksanaan pendidikannya masih rendah otomatis minat belajarnya akan berkurang. Berdasarkan keterangan dari seorang guru Sekolah Dasar di kota Magelang, Kusmilandari menuturkan contoh perbuatan melemahnya motivasi belajar siswa ialah banyak siswa yang menghabiskan tidur selama jam pelajaran berlangsung, siswa mengabaikan penjelasan guru, siswa lebih asyik bermain maupun bercanda dengan teman daripada memperhatikan penjelasan guru, dan lain-lain.

Motivasi belajar menurut Pintrich memiliki makna sebagai memunculkan usaha yang lebih, selama pelajaran berlangsung dan menggunakan strategi yang dapat menunjang proses belajar seperti merencanakan, mengatur dan melatih soal-soal pada materi pelajaran, meninjau tingkat pemahaman suatu materi, serta menghubungkan materi baru dengan ilmu maupun pengetahuan yang sudah dikuasai (Putri \& Soetjiningsih, 2019: 645). Siswa yang memiliki motivasi belajar tinggi juga akan menimbulkan motivasi berprestasi. Sehingga dengan demikian motivasi tersebut dapat memicu siswa untuk bersaing dalam mencapai hasil belajar yang terbaik (Suryana, 2014: 142).

Menurut keterangan dalam buku yang ditulis oleh Dimyati dan Mudjiono, (Dimyati \& Mudjiono, 2013) faktor-faktor yang mempengaruhi motivasi belajar adalah: cita-cita atau aspirasi individu, kemampuan, kondisi individu, kondisi lingkungan siswa, unsur-unsur dinamis dalam belajar dan pembelajaran, serta upaya guru dalam mengajar siswa. Pentingnya upaya guru dalam mengajar siswa tak lepas dari kompetensinya dalam menyampaikan pembelajaran (Wahyudi et al., 2019: 48). Selain faktor-faktor tersebut, adapun faktor psikologis 
dan faktor fisik yang juga mempengaruhi dalam meningkatkan motivasi belajar siswa (Mardiana \& Andriani, 2018: 55). Sehingga apabila sekolah atau lembaga pendidikan memiliki guru yang kompeten akan memperbesar peluang meningkatnya motivasi belajar siswa.

Motivasi belajar yang ditimbulkan individu memiliki keterkaitan kuat pada orientasi belajar siswa itu sendiri, semakin tinggi motivasi belajar siswa maka semakin tinggi peluang ia berhasil memacapai orientasi belajarnya. Sehingga dengan demikian pemberian motivasi yang tepat pada peserta didik akan berdampak pada semangat belajarnya dan memberikan dorongan pada peserta didik untuk mencapai prestasi yang optimal. Sehubungan dengan hal itu motivasi belajar memiliki pengaruh yang positif terhadap hasil belajar (Warti, 2016: 177). Semakin tinggi motivasi belajar siswa maka semakin tinggi pula peluang siswa memperoleh hasil belajar yang baik.

Motivasi belajar dapat diperoleh dari dua faktor yaitu faktor intrinsik, dan faktor ekstrinsik. Akan tetapi selain dari masing-masing faktor intrinsik dan ekstrinsik tersebut, motivasi belajar siswa juga dapat diperoleh dari kombinasi dua faktor tersebut. Motivasi intrinsik adalah dorongan yang diperoleh dari dorongan mental dalam diri individu itu sendiri, yang berkaitan dengan kemauan, kemampuan, tujuan individu itu sendiri dan lain-lain. Sedangkan motivasi ekstrinsik diperoleh dari dorongan luar dirinya atau lingkungannya (Aini, 2016: 92).

Pentingnya motivasi belajar pada siswa Sekolah Dasar sejalan dengan aspirasi dan tujuan individualnya. Hal itu disebabkan fase Sekolah Dasar merupakan langkah pendidikan awal yang ditempuh siswa sebagai jalan menuju masa depannya. Maka dari itu apabila tingkat motivasi belajar siswa Sekolah Dasar tinggi akan berpengaruh pada pencapaian hasil belajarnya. Sehingga motivasi belajar pada diri siswa Sekolah Dasar tersebut harus tetap dipertahankan. Oleh karena itu pada penelitian ini bertujuan untuk menganalisa bagaimana tingkat motivasi belajar siswa Sekolah Dasar yang dipengaruhi oleh faktor intrinsik, faktor ekstrinsik, maupun faktor kombinasi keduanya.

\section{METODE PENELITIAN}

Jenis dari penelitian ini adalah penelitian kuantitatif deskriptif, untuk mengetahui analisa motivasi belajar siswa Sekolah Dasar. Dalam metode pengambilan data dari partisipan menggunakan teknik cluster random sampling. Yaitu teknik megambil sampel dari keseluruhan populasi secara berkelas dari kelompok-kelompok unit yang kecil. Beberapa klaster kemudian 
JURNAL VARIDIKA

Vol. 32, No. 1, 2020, pp.62-70

p-ISSN 0852-0976 | e-ISSN 2460-3953

Website: http://journals.ums.ac.id/index.php/varidika

dipilih secara acak kemudian seluruh elemen dalam klaster terpilih dijadikan sebagai sampel penelitian.

Media yang digunakan untuk mengumpulkan data ialah skala yang merujuk pada Scale of Intrinsic versus Extrinsic Orientation in The Classroom milik Susan Harter tahun 1981. Total skala tersebut berjumlah 30 item kemudian diambil sebanyak 10 item yang paling mendasari kebutuhan penelitan. Jumlah skala tersebut dibagi dalam 5 kategori yakni; Preference for Challenge (Kecenderungan untuk Tantagan), Independent Judgement (Kebebasan dalam menilai diri ), Curiosity Interest (Ketertarikan atau rasa ingin tahu), Independet Mastery (kebebasan dalam penguasaan diri), dan Internal Criteria (Kriteria Internal). Partisipan dalam penelitian ini melibatkan 15 Sekolah Dasar baik Negeri maupun Swasta di kota Magelang. Dari 15 Sekolah Dasar tersebut masing-masing Sekolah diambil sampel sebanyak 4-6 skala untuk setiap kelas secara acak, baik menggunakan kertas maupun google form.

Total data yang berhasil dikumpulkan berjumlah 113 (53 siswa laki-laki dan 60 siswa perempuan) dari 13 sekolah dasar di Kota Magelang. Rentang usia siswa yang menjadi partisipan adalah 7-12 tahun (kelas 1-6). Untuk menganalisis data yang telah dikumpulkan peneliti menggunakan program pengolah data SPSS versi 24.

\section{HASIL DAN PEMBAHASAN}

Motivasi belajar siswa dibentuk dari lima aspek yaitu; kecenderungan menghadapi tangtangan, kebebasan dalam memutuskan, rasa ingin tahu, penguasaan kebebasan, dan kriteria internalnya. Berdasarkan ke-lima aspek tersebut, diperoleh data kecenderungan motivasi belajar siswa dari hasil penilaian guru. Hasil analisis dapat dilihat pada tabel dibawah ini.

Tabel 1. Hasil Uji Statistik Deskripsi

\begin{tabular}{cccccc}
\hline & \multicolumn{5}{c}{ Descriptive Statistic } \\
\cline { 2 - 6 } & $\mathrm{N}$ & Min. & Max. & Mean & Sd. Deviation \\
\hline PC & 113 & 2,00 & 8,00 & 5,4248 & 1,74645 \\
IJ & 113 & 2,00 & 8,00 & 4,1416 & 1,28081 \\
CI & 113 & 2,00 & 8,00 & 4,8142 & 1,32657 \\
IM & 113 & 2,00 & 8,00 & 5,3363 & 2,03369 \\
IC & 113 & 2,00 & 8,00 & 4,0973 & 1,78268 \\
Mot. & 113 & 13,00 & 35,00 & 23,8230 & 4,69085 \\
Valid N & 113 & & & & \\
(listwise) & & & & & \\
\hline
\end{tabular}

Tabel tersebut menjelaskan hasil yang diperoleh dari nilai minimum untuk masingmasing aspek motivasi belajar 113 siswa yakni 2,00, kemudian diperoleh pula nilai 
maksimumnya yakni 8,00 . Selain itu dalam tabel tersebut juga dicantumkan nilai mean dari masing-masing aspek, yaitu; Preference for Challenge 5,4248, Independent Judgement 4,1416, Curiosity Interest 4,8142, Independet Mastery 5,3363, dan Internal Criteria 4,0973 maupun keseluruhannya yaitu 23,8230.

Selanjutnya, berikut merupakan hasil pesentase dari masing-masing aspek :

Tabel 2. Preference for Challenge

\begin{tabular}{lll}
\hline & F & \multicolumn{2}{c}{$\%$} \\
\hline Ekstrinsik & 35 & 31,0 \\
Kombinasi & 32 & 28,3 \\
Instrinsik & 46 & 40,7
\end{tabular}

Tabel di atas menunjukkan kecenderungan motivasi belajar dari 113 siswa. Sebanyak 35 siswa memiliki kecenderungan motivasi belajar ekstrinsik, dengan persentase $31 \%$ dari total keseluruhan 100\%. Adapun 32 siswa memiliki kecenderungan motivasi belajar kombinasi dengan presentase $28,3 \%$. Serta sebanyak 46 siswa memiliki kecenderungan motivasi belajar intrinsik, dengan persentase 40,7\%. Dengan demikian motivasi belajar siswa dari 113 siswa pada kategori preference for challenge (kecenderungan untuk tantangan), lebih didominasi oleh motivasi internal yakni sebanyak $40,7 \%$ atau sebanyak 46 siswa.

Tabel 3. Independent Judgement

\begin{tabular}{ccc}
\hline & $\mathrm{F}$ & $\%$ \\
\hline Ekstrinsik & 67 & 59,3 \\
Kombinasi & 39 & 34,5 \\
Instrinsik & 7 & 6,2
\end{tabular}

Untuk aspek motivasi belajar kategori Independent Judgement (kebebasan dalam menilai diri), dari total 113 siswa diperoleh hasil sebanyak 59,3\% atau 67 siswa memiliki kecenderungan motivasi belajar ekstrinsik. Sedangkan 34,5\% atau 39 siswa memiliki kecenderungan motivasi belajar kombinasi, serta hanya 6,2\% atau 7 siswa yang memiliki kecenderungan motivasi belajar intrinsik. Itu artinya hanya ada 7 siswa dari 113 sisiwa yang mampu menilai kemampuan dirinya sendiri. 
Tabel 4. Curiosity Interest

\begin{tabular}{lrr}
\hline & F & \multicolumn{2}{c}{$\%$} \\
\hline Ekstrinsik & 32 & 28,3 \\
Kombinasi & 71 & 62,8 \\
Instrinsik & 10 & 8,8
\end{tabular}

Berbeda dengan kategori Preference for Challenge, pada kategori Curiosity Interest (ketertarikan/rasa ingin tahu) diperoleh hasil sebanyak 71 dari 113 siswa memiliki kecenderungan motivasi belajar kombinasi dengan persentase $62,8 \%$. Selain itu sisanya yakni 32 orang memiliki kecenderungan motivasi belajar ekstrinsik dengan persentase 28,3\%, dan 10 siswa memiliki kecenderungan motivasi belajar intrinsik dengan persentase 8,8\%.

Tabel 5. Independet Mastery

\begin{tabular}{lcr}
\hline & F & \multicolumn{2}{c}{$\%$} \\
\hline Ekstrinsik & 41 & 36,3 \\
Kombinasi & 36 & 31,9 \\
Instrinsik & 36 & 31,9
\end{tabular}

Pada kategori Independet Mastery (kebebasan dalam penguasaan diri) diperoleh hasil sebanyak 41 siswa memiliki kecenderungan motivasi belajar ekstrinsik dengan persentase 36,3\%. Sedangkan untuk kecenderungan motivasi belajar ekstrinsik dan intrinsik memiliki kesamaan hasil yakni masing-masing terdapat 36 siswa dengan masing-masing persentase $31,9 \%$.

Tabel 6. Internal Criteria

\begin{tabular}{lcc}
\hline & F & \multicolumn{2}{c}{$\%$} \\
\hline Ekstrinsik & 75 & 66,4 \\
Kombinasi & 25 & 22,1 \\
Instrinsik & 13 & 11,5
\end{tabular}

Tabel tersebut menggambarkan hasil pada kategori aspek motivasi belajar yang terakhir yaitu Internal Criteria (kriteria internal). Sebanyak 75 siswa mendominasi kecenderungan motivasi belajar eksentrinsik dengan persentase 66,4\%. Selain itu 25 siswa memiliki kecenderungan motivasi belajar kombinasi, dengan persentase 22,1\%. Serta sisanya yaitu 13 anak kecenderungan motivasi belajar intrinsik dengan persentase 11,5\%.

Total keseluruhan, maka hasil yang diperoleh digambarkan dalam bentuk tabel dan diagram sebagai berikut: 
Tabel 7. Akumulasi aspek motivasi

\begin{tabular}{lcc}
\hline & F & \multicolumn{2}{c}{$\%$} \\
\hline Ekstrinsik & 35 & 31,0 \\
Kombinasi & 57 & 50,4 \\
Instrinsik & 21 & 18,6
\end{tabular}

Dari ke-lima kategori aspek motivasi belajar diatas, diperoleh hasil akumulasi akhir dari seluruh aspek, yaitu sebanyak 35 siswa dari 113 siswa memiliki kecenderungan motivasi belajar ekstrinsik dengan persentase 31\%, sebanyak 57 siswa kecenderungan motivasi belajar kombinasi dengan persentase 50,4\%, dan 21 siswa kecenderungan motivasi belajar intrinsik dengan persentase $18,6 \%$. Adapun diagram dibawah ini untuk menggambarkan persentase masing-masing aspek motivasi belajar siswa:

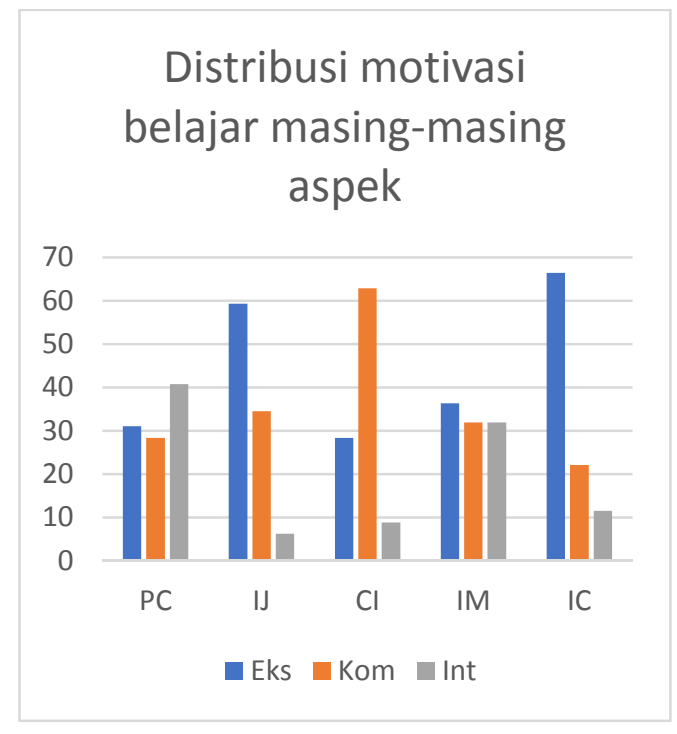

Gambar 1. Diagram Distribusi Motivasi

Apabila dilihat dari diagram di atas setiap aspek kebanyakan siswa cenderung memiliki motivasi ekstrinsik. Hal ini menunjukkan bahwa kebanyakan siswa masih menilai sesuatu berdasarkan lingkungan bukan atas dasar keinginan atau nilai-nilai yang dianut anak itu sendiri.

Setelah memahami seluruh deskripsi diatas, maka dapat diketahui bahwa siswa Sekolah Dasar di kota Magelang rata-rata memiliki motivasi belajar kombinasi antara ekstrinsik dan intrinsik cukup tinggi. Hal itu diperoleh dari hasil akumulasi seluruh aspek motivasi yakni sebanyak 50,4\%. Sehingga dengan demikian 49,6\% sisanya, siswa yang memiliki motivasi 
belajar ekstrinsik sebanyak 31\% itu berarti motivasi belajar ekstrinsik siswa SD di kota Magelang berada ditingkat sedang. Serta 18,6\% siswa SD di kota Magelang memiliki motivasi belajar intrinsik.

Oleh karena itu tingkat motivasi belajar intrinsik pada siswa Sekolah Dasar di kota Magelang lebih rendah, dibandingkan dengan motivasi belajar ekstrinsik maupun motivasi belajar kombinasinya. Tingginya tingkat motivasi belajar kombinasi siswa SD di kota Magelang, menunjukkan bahwa peran internal diri siswa dan lingkungan bekerjasama dengan baik. Apabila motivasi belajar siswa dipertahankan sejak dini, maka kedepannya siswa akan memiliki peluang keberhasilan yang besar untuk mencapai tujuan belajar maupun cita-cita. Hal itu disebabkan motivasi belajar merupakan faktor pendorong, yang membantu siswa dalam meraih aspirasi belajarnya.

Berdasarkan penelitian yang dilakukan sebelumnya menyatakan bahwa aspek yang mempengaruhi motivasi belajar yaitu adanya reward dan punishment. Reward dan punishment memberikan pengaruh besar terhadap motivasi belajar siswa. Strategi yang tepat akan mempengaruhi proses pembelajaran semakin meningkat secara terus menerus (Ernata, 2017). Untuk itu guru senantiasa berupaya memotivasi siswa melalui berbagai cara yaitu dengan memberikan dukungan bahwa siswa mampu melakukan hal tersebut maupun motivasi yang diperoleh dari dalam siswa sendiri yang berkaitan dengan kemauan dan kemampuan siswa.

Dalam penelitian ini ditemukan bahwa motivasi belajar pada siswa tidak hanya diperoleh dari faktor instrinsik maupun ekstrinsik saja namun keduanya berperan bersama dalam memotivasi siswa dalam hal belajar. Siswa tidak hanya mendapat kepercayaan diri namun mendapat dukungan dari lingkungan.

\section{SIMPULAN}

Pada penelitian ini ditemukan bahwa motivasi belajar siswa Sekolah Dasar di kota Magelang bukan karena faktor reward, punishment, dan reinforcement seperti pada penelitian sebelumnya. Melainkan, karena adanya kombinasi faktor intrinsik dan ekstrinsik. Sehingga sesuai dengan hasil analisa yang telah dipaparkan, motivasi belajar siswa Sekolah Dasar di kota Magelang memiliki kecenderungan motivasi belajar kombinasi dengan persentase 50,4\% dari (57 siswa) dari 113 siswa Sekolah Dasar di Kota Magelang memiliki tingkat motivasi belajar kombinasi yang tinggi. Sementara 49,6\% (35 siswa) sisanya terbagi dalam kategori aspek 
motivasi belajar ekstrinsik yakni 31\% dari 113 siswa, dan 18,6\% (21 siswa) dari 113 siswa memiliki kecenderungan motivasi belajar intrinsik.

\section{REFERENSI}

Aini, Q. (2016). Pengaruh Motivasi Belajar Intrinsik dan Ekstrinsik terhadap Prestasi Belajar Ekonomi di SMA NW Pancor Lombok Timur NTB. 10(2), 91-96.

Dimyati, \& Mudjiono. (2013). Belajar dan Pembelajaran. PT Rineka Cipta.

Ernata, Y. (2017). Analisis Motivasi Belajar Peserta Didik Melalui Pemberian Reward dan Punishment. Jurnal Pemikiran Dan Pengembangan SD, 5(September), 781-790.

Fauzie, Y. Y. (2018). Kualitas Pendidikan Indonesia Masih Rendah. CNNIndoneisa. https://m.cnnindonesia.com/gaya-hidup/20180607113429-284-304214/bank-duniakualitas-pendidikan-indonesia-masih-rendah

Mardiana, \& Andriani, L. (2018). Faktor-Faktor yang Mempengaruhi Motivasi Belajar dalam Upaya Meningkatkan Hasil Belajar Siswa pada Mata Pelajaran Ekonomi di SMA Purnama 2 Kota Jambi. Scientific Journals of Economic Education, 2(September), 4656.

Permana, R. H. (2019). RI Sepuluh Besar Dari Bawah. detikNews. https://m.detik.com/news/berita/d-4808456/survei-kualitas-pendidikan-pisa-2018-risepuluh-besar-dari-bawah

Putri, C. G., \& Soetjiningsih, C. H. (2019). Jurnal Mitra Pendidikan ( JMP Online ). Journal Mitra Pendidikan, 3(5), 644-656.

Suryana, M. F. (2014). Optimalisasi Motivasi Berprestasi dan Pendidikan Karakter Dampaknya terhadap Prestasi Belajar Materi Himpunan Melalui Pendekatan Konstruktivisme Pada Siswa Kelas VII D SMP Negeri 3 Teras Kabupaten Boyolali Semester Gasal Tahun Pelajaran 2014/2015. Jurnal Varia Pendidikan, 26, 141-156.

Wahyudi, A., Narimo, S., \& Wafroturohmah. (2019). Kepemimpinan Pembelajaran Kepala Sekolah dalam Meningkatkan Hasil Belajar Siswa. Jurnal Varidika, 31(2), 47-55. https://doi.org/10.23917/varidika.v31vi2i.10218

Warti, E. (2016). Pengaruh Motivasi Belajar Siswa terhadap Hasil Belajar Matematika Siswa di SD Angkasa 10 Halim Perdana Kusuma Jakarta Timur. Jurnal Pendidikan Matematika, 5, 177-185. 